\title{
Two Cases of Nasal Glioma Treated by Endoscopic Transnasal Surgery
}

\author{
Endoskopik Transnazal Cerrahi ile Tedavi Edilen Iki Nazal Gliom Olgusu
}

\section{Abdulkadir Özgür1', Engin Dursun1, İbrahim Șehitoğlu², Zerrin Özergin Coșkun', Özlem Çelebi Erdivanlı', Suat Terzi ${ }^{1}$}

${ }^{1}$ Recep Tayyip Erdoğan University Faculty of Medicine, Department of Otorbinolaryngology, Rize, Turkey; ${ }^{2}$ Recep Tayyip Erdoğan University Faculty of Medicine, Department of Pathology, Rize, Turkey

\begin{abstract}
Nasal glioma is a rare congenital benign midline tumor consisting of heterotropic glial tissue. Similarly, to the other intranasal tumors it causes symptoms like nasal obstruction, rhinorrhea, and bleeding. The only treatment option is surgical excision. Since the tumor recurrence is a very common condition the surgery should be performed very carefully. In addition, in cases with intracranial extension fatal postoperative meningitis may occur. In this report, we aimed to present clinical and therapeutic features of the two cases of nasal glioma patient which were both treated by transnasal surgery at the age of nine months and thirteen months old.
\end{abstract}

Key words: endoscopic transnasal surgery; congenital midline tumors; nasal glioma

\section{ÖZET}

Nazal gliomlar heterotropik glial dokudan olușan, nadir görülen, kongenital benign orta hat tümörleridir. Diğer intranazal tümörlere benzer șekilde burun tıkanıklığı, burun akıntısı ve burun kanaması gibi semptomları vardır. Tek tedavi seçeneği cerrahi eksizyondur. Fakat cerrahisi çok dikkatli yapılmalıdır. Çünkü tümör nüksü çok sık karșılașılan bir durumdur. Ayrıca intrakraniyal uzanımı olan vakalarda ölümcül seyredebilen postoperatif menenjit ortaya çıkabilir. Bu yazıda biri dokuz aylık, diğeri ise on üç aylıkken transnazal cerrahi tedavi uygulanan iki nazal gliom vakasının klinik ve tedavi özelliklerinin sunulması amaçlanmıștır.

Anahtar kelimeler: endoskopik transnazal cerrahi; konjenital orta hat tümörleri; nazal gliom

\section{Introduction}

Nasal gliomas are very rare benign tumors formed by presence of heterotopic glial tissue on the nasal dorsum and/or nasal cavity congenitally. There are intranasal, extranasal and mixed types. Although most commonly seen in the nasal area; can also occur in other areas such as skin, palate, orbit, scalp and lungs ${ }^{1,2}$. It is frequently diagnosed in newborn and pre-school ages, however, can be also observed in adults in very rare amount ${ }^{3}$. Similarly to other intranasal masses, patients with intranasal localization have symptoms like nasal obstruction, rhinorrhea, and bleeding. Those located extranasally can cause cosmetic deformities. Clinically, these tumors are often seen as hard, non-pulsatile and gray or pink colored masses ${ }^{1,4}$. Treatment choice is surgical excision. Although rarely seen, they are nevertheless clinically important tumors because of the possibility of connection with central nervous system. After excision or biopsy cerebrospinal fluid (CSF) leakage or meningitis may occur 5 .

\section{Case 1}

Thirteen month old baby boy was admitted with complaint of a mass protruding from the left nasal vestibule existing since birth. The physcical examination of the patient showed a mass filling the left nasal cavity with stiff elastic consistency. A magnetic resonance imaging (MRI) was performed to determine the localization and possibility of intracranial extension of the mass. It showed a $9 \times 16 \times 20 \mathrm{~mm}$ cystic mass filling the the left nasal cavity and pushing the middle turbinates. There was no intracranial connection (Fig. 1). 

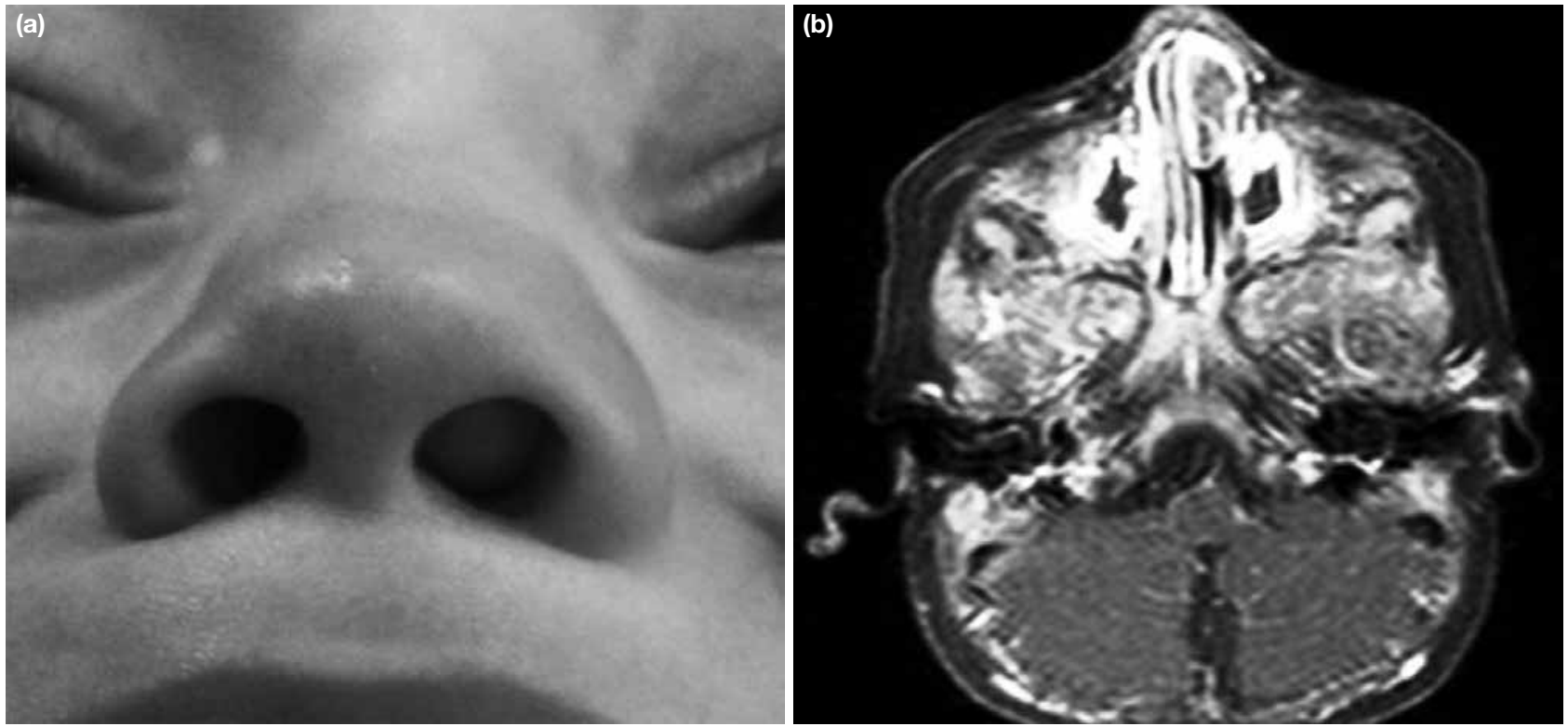

Figure 1. $\boldsymbol{a}, \boldsymbol{b}$. The mass filling the left nasal cavity (a). MRI of the tumor in axial plan (b).

(a)

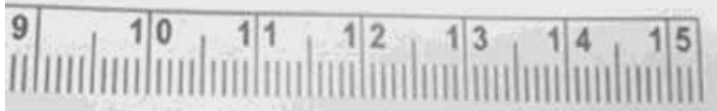
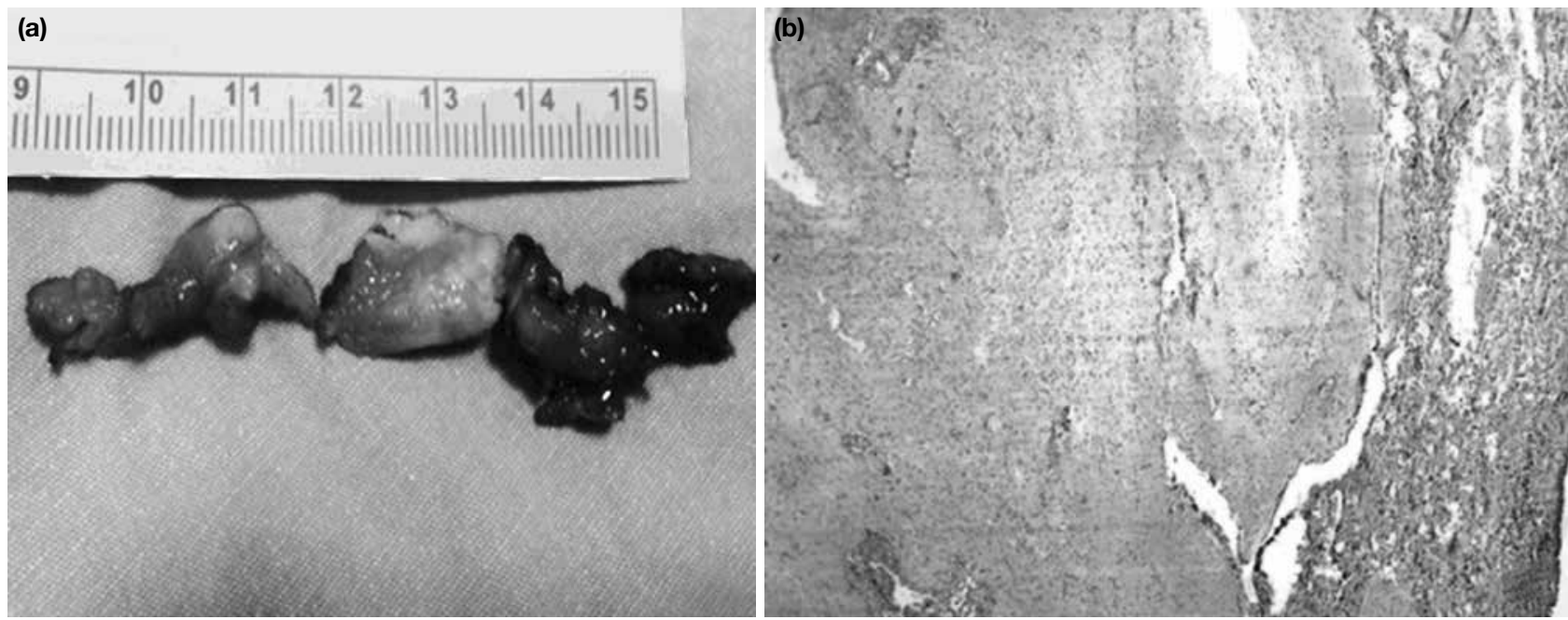

Figure 2. $\boldsymbol{a}, \boldsymbol{b}$. The macroscopic appearance of the excised mass (a). The microscopic appearance of the mass (the eosinophilic glial tissue located just under the pseudo-stratified epithelium [H\&Ex40]) (b).

Total tumor excision with endoscopic transnasal surgery was performed under general anesthesia with a preliminary diagnosis of nasal glioma. During the operation, the tumor was seen partially adhered to the mucosa of the nasal septum and so the adjacent septal mucosa was excised with the mass. The postoperative pathologic examination of the excised specimen confirmed the diagnose of nasal glioma (Fig. 2). There was no major complication or recurrence during the postoperative two years follow up.

\section{Case 2}

Nine month old baby boy was admitted to the to our clinic with the complaint of a mass in the right nasal cavity that led to progressive respiratory distress after birth. The physical examination of the patient showed a mass filling the right nasal cavity with hard elastic consistency. MRI of the patient revealed a cystic mass in the right nasal cavity which was approximately $7 \times 15 \times 22 \mathrm{~mm}$ in size without significant enhancement. There was no intracranial extension (Fig. 3). 

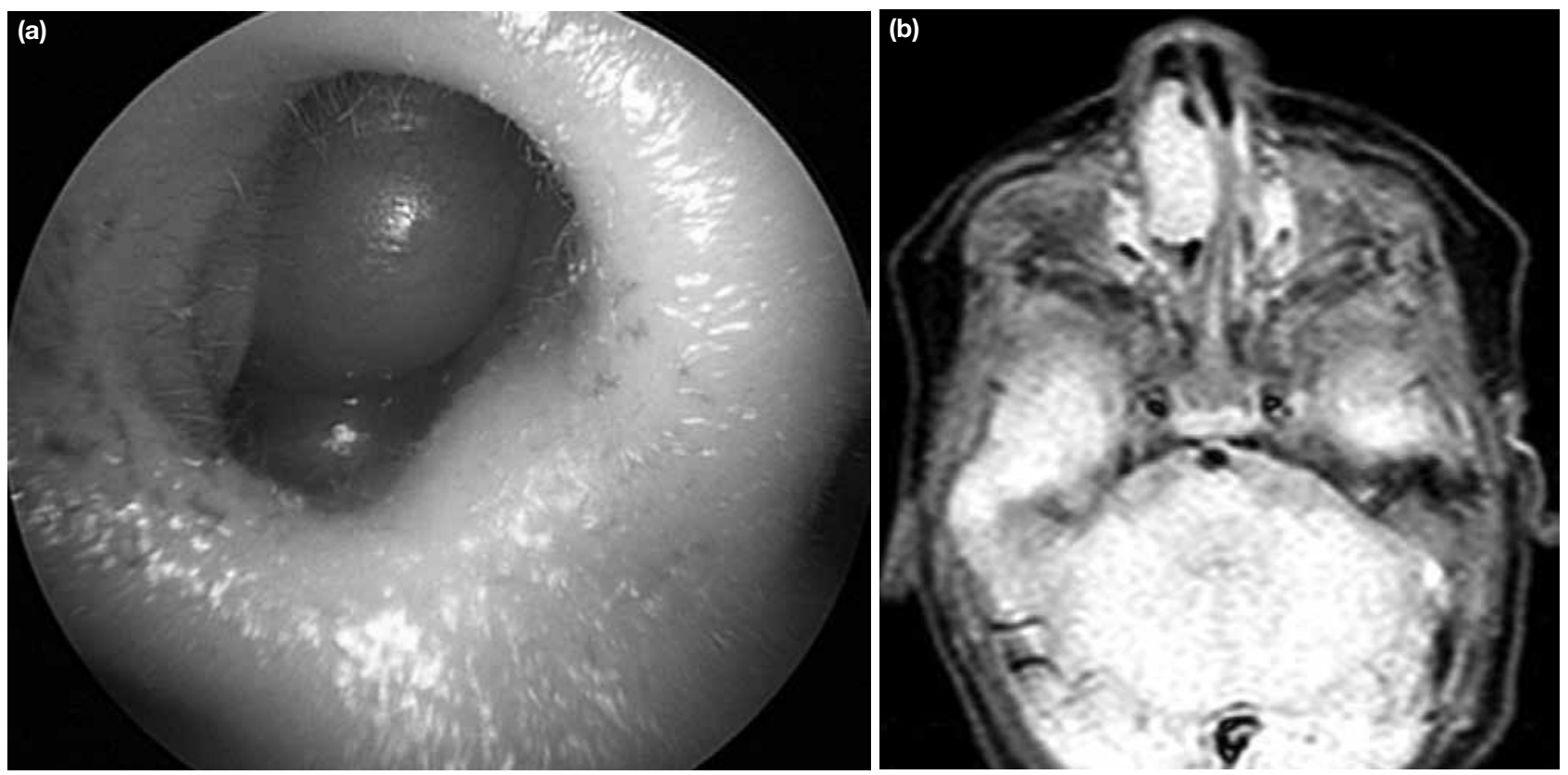

Figure 3. a, b. The mass filling the right nasal cavity (a). Preoperative MRI of the patient in axial plan (b).
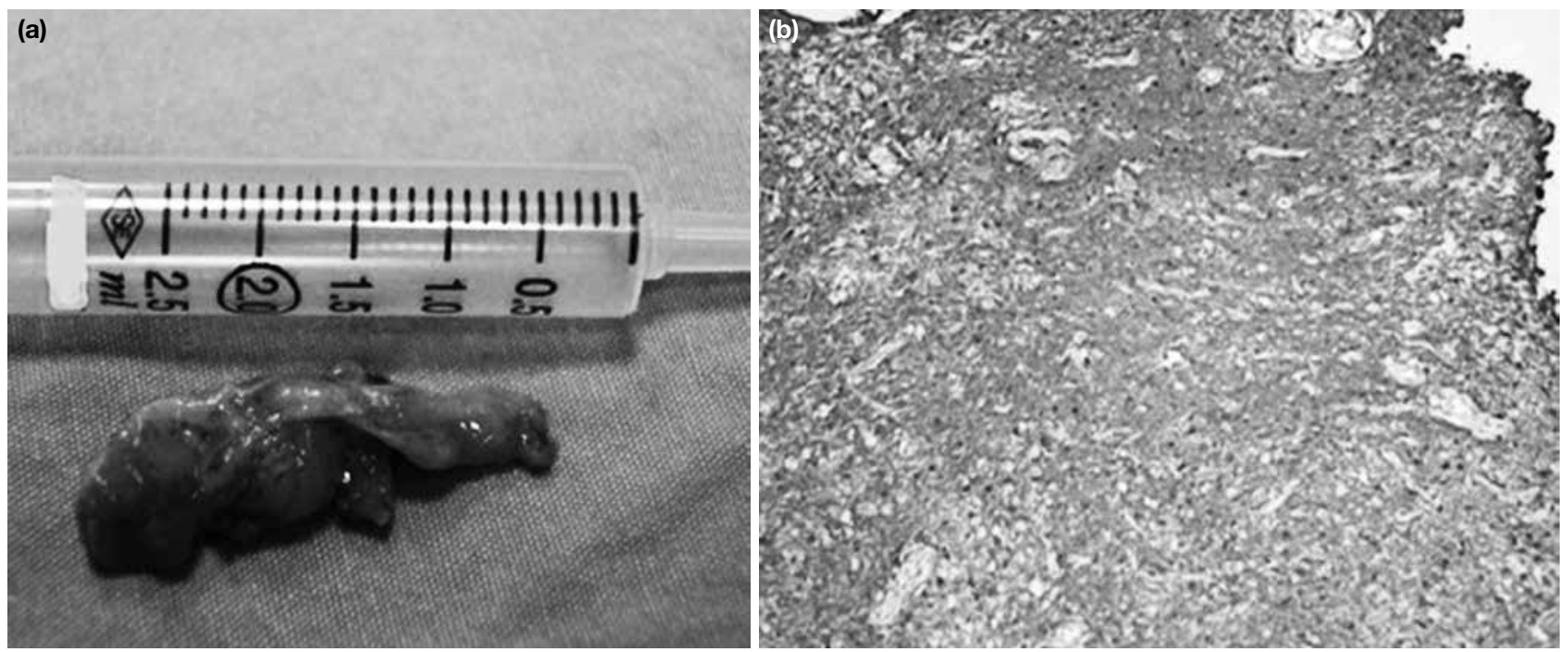

Figure 4. Postoperative macroscopic appearance of the excised tumor and microscopic appearance of it (diffuse and strong glial fibrillary asidic protein involvement in glial tissue, $\times 100$ ).

Total tumor excision with endoscopic transnasal surgery was performed under general anesthesia with a preliminary diagnosis of nasal glioma. The postoperative pathologic examination comfirmed the diagnose (Fig. 4). There was no recurrence or major complication during the postoperative eighteen months follow-up.

\section{Discussion}

Congenital midline nasal masses are very rare anomalies. The most common forms are dermoid cysts, nasal gliomas, encephaloceles and hemangiomas ${ }^{6}$. Nasal glioma is not a real tumor. During embryonic development, as a result of the abnormal closure of the nasal and frontal bones it occurs as extracranial settlement of ectopic glial tissue. Histologically, it is composed of 
glial cells and neuroglial elements in the matrix within the connective tissue. Therefore, it is also called as glial heterotropia by some authors. Nasal gliomas may be associated with subarachnoid space or dura ${ }^{4,5}$. It is frequently seen in infants and preschool-age but very rarely can be also observed in adults. Clinically,it can be seen in the form of extranasal (60\%), intranasal (30\%) or mixed type $(10 \%)^{3}$. The cases presented were thirteen and nine months male patients and the masses were located intranasally and presented just after the birth.

Similar to other intranasal tumors, intranasal glial heterotopia can cause symptoms like nasal obstruction, rhinorrhea, and bleeding. Clinically, these tumors are often seen as hard, non-pulsatile and gray or pink colored mass ${ }^{1,4}$. Clinical findings and preoperative imaging methods, such as computed tomography and MRI can not distinguish nasal gliomas from the other midline masses (dermoid cyst, teratoma, hemangioma, lipoma etc.). Histopathological and immunohistochemical examination is needed for the differential diagnosis. Preoperative imaging techniques are used for evaluation of the boundaries of the mass and relationship of it with the surrounding tissues ${ }^{2}$. To support the diagnosis of nasal glioma neuron-specific antigens such as neuron specific enolase (NSE), glial fibrillary asidic protein (GFAP) and S-100 protein examination can be performed immunohistochemically ${ }^{1}$. In the cases presented MRI was used as preoperative imaging technique and it did not show any intracranial connection or invasion into surrounding tissues. Immunohistochemical examination of the excised specimens showed NSE, GFAP and S-100 protein positivity.
Treatment choice is surgical excision. Lateral rhinotomy approach or endoscopic surgical methods can be applied in intranasal masses. After excision or biopsy complications such as CSF leak and recurrent meningitis may occur. Nowadays transnasal endoscopic surgery is more preferred since the use of it is minimally invasive ${ }^{1,5}$. In both of the cases presented here, masses were excised completely with transnasal endoscopic surgery. In the follow-up of our cases there was no recurrence or complication observed.

As a result; nasal glioma should be kept in mind in the differential diagnosis of patients presenting with nasal mass especially in the newborn and infancy period. Treatment choice is total excision of the tumor and we believe that endoscopic transnasal surgery could be performed as a minimally invasive method in the management of the disease.

\section{References}

1. Yokoi H, Wada R, Ichikawa G. Endoscopic treatment of socalled intranasal glioma. Rhinology 2002;40:217-9.

2. Ramadass T, Narayanan N, Rao P, et al. Glial Heterotopia in ENT-Two Case Reports and Review of Literature. Indian J Otolaryngol Head Neck Surg 2011;63:407-10.

3. Penner CR, Thompson L. Nasal glial heterotopia: a clinicopathologic and immunophenotypic analysis of 10 cases with a review of the literature. Ann Diagn Pathol 2003;7:354-9.

4. Sürmelioğlu Ö, Tarkan Ö, Tuncer Ü, et al. Nasal Glioma: Case report. Cukurova Med J 2011;36:34-6.

5. Talwar OP, Pradhan S, Swami R. Nasal glioma: a case report. Kathmandu Univ Med J 2007;5:114-5.

6. Ma KH, Cheung KL. Nasal glioma. Hong Kong Med J 2006;12:477-9. 